Article

\title{
Managing Multiplicity: Adult Children of Post-Independence Nigerians and Belonging in Britain
}

\author{
Julie Botticello \\ School of Health, Sport and Bioscience, University of East London, London, E15 4LZ, UK; E-Mail: j.a.botticello@uel.ac.uk
}

Submitted: 18 September 2019 | Accepted: 31 January 2020 | Published: 25 March 2020

\begin{abstract}
Migration remains a contentious and divisive topic, particularly with the rise of xenophobia and far right ideologies, which seek to demonize migrants as neither belonging nor welcome in the host society. This reduction leaves the realities of postcolonial migrants as misunderstood and misrepresented. Particularly misunderstood are the children of post-colonial migrants, who were born and raised in the UK by families seeking to better themselves in the 'Mother land,' while also aiming to maintain connectivity to traditions and practices from homelands. For some children born in the UK to Nigerian émigrés, family crises precipitated the need for alternative care arrangements, entailing recourse to fostering, boarding schools, or institutional care for periods of time during childhood. Conflicts between British society's and parents' cultural values, overt racism and hostility from host society, and differential experiences of extra-family care have impressed upon these children, now adults, both their multiple exclusions and potential belongings. As a result of their traumatic experiences, these adults, now in their 50 s and 60 s, embody multiculturalism in their abilities to embrace, navigate, and endure in a host country that expresses unwillingness at best and outright hostility at worst toward their presence as UK nationals and progeny of the project of Empire. While continuing to be framed by harsh micro- and macro-conditions, these adult children reveal that belonging can be self-determined through choices on how and with whom they choose to live and grow.
\end{abstract}

\section{Keywords}

belonging; children; decolonization; family; fostering; migration; Nigerians; post-colonialism; racism

\section{Issue}

This article is part of the issue "Boundary Spanning and Reconstitution: Migration, Community and Belonging" edited by Anya Ahmed (University of Salford, UK).

(C) 2020 by the author; licensee Cogitatio (Lisbon, Portugal). This article is licensed under a Creative Commons Attribution 4.0 International License (CC BY).

\section{Introduction}

This article concerns a small sample of secondgeneration children born to mid-20th century Nigerian émigrés to the UK and aims to understand their experiences of belonging and identity in British society, amid the occurrence of extra-family care within the UK. This article focuses on three individuals who, in addition to being born to Nigerian émigrés, also spent some or all of their childhoods outside of their natal households and in an institutionalized form of care-in a foster home, in a care home, or in boarding school-in the UK. The article recounts some of their challenges for belonging in relation to their parents' cultures, while also coping with the hostilities of being both 'other' and British. Not aiming to represent the experience of all children born in the UK to Nigerian parents in the independence period, this article nevertheless suggests that their experiences are not anomalous but are part of a historical phenomenon attending decolonization and the crises visited upon postcolonial migrants at Empire's end. As Bailkin (2009, p. 96) comments, "the "problem" of African children in Britain constitutes an important field for reevaluating the impact of decolonization on metropolitan family life.' Yet, the origin of this 'problem' was not then and is not now these (adult) children, who have palpably understood the impacts of post-colonialism and Britain's resistance to becoming 'dispersed' and 'plural' (Modood, 2010, 
p. 124). Rather, the problem remains with the hostile and racist society that perceives people of color with alternative origins and practices as threats to the myths and narratives of Britishness. Although the UK has been in its post-colonial era since the 1960 s, and with a multicultural stance since the 1980s, the rhetoric of British subjects not belonging in Britain persists.

\section{Context and Conceptual Framework}

Post-colonial migration, political discourse, and the end of Empire went hand in hand. Britain welcomed migration from former colonies, both to buoy its economy in the aftermath of WWII and to support the transition to native rule of the newly independent nations. As Nigeria had been run successfully via indirect rule (Harris, 2006; Imoagene, 2012), many Nigerians came to Britain to gain educational qualifications to become civil servants upon their return. Bailkin (2009, p. 88) reveals that there were 11,000 African students on scholarships in the UK in 1960, plus 10,000 s of privately funded students. However, 'what was for Nigeria the dawn of independence was for Britain the end of Empire' (Harris, 2006 , p. 38), and as the 1960 s progressed, Britain descended into economic decline, recession, and structural unemployment.

The initial welcome of the post-independence period was by the mid-1960s transformed into barriers, through legislation in the UK and in Nigeria that tightened measures to enter or leave, respectively (Bailkin, 2009, p. 90). This was not simply economic, but ideological. As Ellis (2001, p. 230) contends, 'Britain was shifting its national identity from an external, global plane in 1948, to an internal, local plane' a decade later and that those emigrating from the reaches of Empire were perceived as a 'source of...anxiety.' Gilroy sees these two as intrinsically connected: Britain's inability to 'mourn its loss of Empire and to accommodate the Empire's consequences' (Gilroy, 2004, p. 111), and its perception of immigration as 'akin to war and invasion' (Gilroy, 2004, p. 102). PostEmpire migrants moving from periphery to center were subjected to 'an ontological transformation' of identity from being 'British subject to foreign immigrant' (Ellis, 2001, p. 215), leaving former members of Empire estranged within Britain itself.

While contending with these difficulties, immigrating Nigerians were also concerned with their personal and traditional ambitions to have children (Oyetade, 1993, p. 84). Onus for childbearing was with women, yet, the 'conflict between their productive and reproductive roles affected both partners' (Harris, 2006, p. 33). Without extended family, child rearing had to be negotiated. In 1968, up to 5000 African children were privately fostered in the UK (Bailkin, 2009, p. 88) to assist in the stresses of achieving productive and reproductive goals. Fostering or other care pathways were viable options, as for some cultures, child circulation is normative and not viewed as a form of neglect (Wells, 2019, p. 275). While there is a practice of children in Nigeria being raised by other than birth parents, in which parents may seek 'social advantages for their children' (Goody, 1978, as cited in Bailkin, 2009, p. 105) or to 'sediment and mobilize networks' (Wells, 2017, p. 218), it can be argued that fostering/care in post-colonial Britain was different in kind. Considering recent transnational fostering situations in the UK, Wells $(2017,2019)$ argues that a crisis, such as family breakdown, is more often the catalyst for seeking care from outside natal family. Bailkin (2009, p. 106) similarly argues for 'exigency' rather than 'culture' to understand extra-family child-care among first-generation West Africans as an outcome of 'economic necessity and the pressures of migration.' As she laments, if upon the student were pinned the hopes for a newly independent Africa, upon the child was 'the damage inflicted by the former Mother country at Empire's end' (Bailkin, 2009, p. 118).

Balibar argues that a 'new racism' was experienced in Britain in the latter part of the 20th century (as cited in Modood, 1997, pp. 154-155). This she says was linked to the negative reception of reverse movements from the peripheries to the center, raising questions about who could be or become British. As Yuval-Davis (2004, p. 220) argues, this denial is based on the myth of a 'fixed, immutable, ahistorical and homogenous construction of the collectivity's culture.' These ideologies of exclusion spread beyond the first generations to encompass their UK born children, deterministically perceived as 'other' in their birth land. As Yuval-Davis (1997, p. 193) comments, 'otherness serves as a basis for legitimizing the exclusion and/or subordination and/or exploitation of members of the collectivity thus labelled.' For children born in the UK, contending with othering has become a life-long project; one whose origin can be traced to the myths of British nationality and, as Gilroy (2004) notes above, Britain's inability to accommodate the consequences of Empire. In particular, the difficulty in reconciling its national identity as pluri-ethnic and pluri-cultural, rather than one of 'solidaristic monism' (Modood, 1997, p. 170).

In Powell's infamous Rivers of Blood speech from 1968 , he contended that those from the former colonies could not become English, even if born in England. As he states, 'the West Indian or Asian does not, by being born in England, become an Englishman. In law he becomes a United Kingdom citizen by birth; in fact, he is a West Indian or an Asian still' (Powell, 1991, p. 393). This duality reflects the manifestation of exteriorized hostility underpinning the ontological turn of transforming British subjects, regardless of where they are from, into unwelcome foreigners, though such dualisms underestimate the multiplicity of exclusion or belonging. Further, such cultural determinism raised 'doubts about the possibility of assimilating cohesive "alien" minorities into the nation' (Modood, 1997, p. 169). This attitude within the seat of Empire was not just rhetoric; it was enshrined in doctrine and practice. Yuval-Davis (2004, p. 219) notes 
that since the beginning of the 20th century, innumerable immigration regulations, often with racial biases, have been set up and continue to effect migrants today (Yuval-Davis, Wemys, \& Cassidy, 2018).

The practice also took place in a less overt way, where 'indifference' (Bell, 2018), by not making legislation, equally contrived to exclude and alienate. Bailkin (2009, p. 107) states that 'the demands of peaceful decolonization were explicitly at odds with child protection.' She argues that Britain attended to African parents-enabling their entry as workers or students who would be returning to run their independent nations-and took an indifferent approach to their children, as Britain did not wish to appear paternalistic or interfering. In this case, both the 'Home Office and the Colonial Office...championed a doctrine of nonintervention' (Bailkin, 2009, p. 109) toward children being raised in private fostering arrangements. Yuval-Davis (1997, p. 195) notes how family is a site for the reproduction of the collectivity. According to British postcolonial policy, Nigerian parents were reproducing children in the UK not for the collectivity of a multi-ethnic Britain, even when being raised in British institutions (i.e., foster homes, care homes, boarding schools), but for reabsorption into a conveniently assumed congruent (Yuval-Davis, 2004, p. 218) and homogenous land, Nigeria, of little concern to the center.

While this article does not directly engage with those first-generation Nigerians who emigrated to the UK at independence, it does reveal, through discussions with their children, the difficulties their parents faced at Empire's end. The increasingly unwelcoming and hostile circumstances encountered from the mid-20th century beleaguered parents' processes of return, and their protracted stays transformed both themselves and their children into something other than temporary visitors.

\section{Methodology}

This work is part of a larger project undertaken for my doctoral study over the period 2004-2009, augmented with supplementary research undertaken in 2019. For the earlier work, I conducted ethnographic and participant observation research in street markets, in faith communities, and at personal or national celebratory events with a focus on first generation Yoruba Nigerians, predominantly based in South London. This was supplemented by a site visit in 2007 to Nigeria, including lle-Ife, the heart of Yorubaland, and Lagos, to understand better why contemporary Nigerians wished to leave and what they hoped to gain by coming to the UK. In addition to the participatory fieldwork, I conducted semi-structured interviews in the UK and in Nigeria with 20 research participants, holding up to five interviews each with core participants, each ranging from 45 to 90 minutes in duration.

The communal work was aimed at understanding groupings of solidarity within a cosmopolitan setting (Botticello, 2012), while also attending to individual self- realization within groups (Botticello, 2009). For the first generations, my research found that migration meant potential fulfillment of aspirations for social recognition and material gain, invoked through the Yoruba Nigerian tenet of the good life-owo/money, omo/children, and alaafia/health or peace (Hallgren, 1991). The doctoral research followed a precedent set in anthropological literature about African societies and the purpose of migration, in which the frontier (Kopytoff, 1986) remains essentially a conservative space where societies reproduce themselves, albeit under new conditions. In the process of migration, additional social, material and economic resources could be assimilated within a conceptual framework of expansion and binding, in which incorporation as well as repetition functioned to reproduce oneself in the world. This notion of expansion and binding regarding children relates more to their parents' conception of what children will do for them, in the form of extending parents' networks of possibility, as noted by Goody (1978, as cited in Bailkin, 2009) and Wells (2017) above. In the thesis, I argued that from children's perspectives, especially for those who were raised for some periods outside their Nigerian households, expansion led to alienation as there were not enough social, historical, and experiential connections to be successfully rebound within their parents' culture. Rather, the children gained expansive, though not necessarily positive, lives and experiences, and became something further. In this process, it could be argued that they became multicultural, able to navigate multiple environments, but at the same time, due to the generic notions of culture as fixed, unchanging and homogenous (Yuval-Davis, 2004), they also became marginal to the fixed communities of belonging on offer-English, British, or Nigerian.

When I began my fieldwork in 2005, I personally knew no Nigerians. As I had been living in South London since the late 1980s, I was very aware of the presence of Nigerians, but this awareness had not moved beyond a shared physical geography. I began to connect through recommendations of people I knew-my daughter's math teacher at school, a friend's upstairs neighbor, another friend's friend who was a market trader, a Nigerian academic's connection to a local Yoruba church. More and deeper connections grew from these initial introductions, in particular the church and market. In the earliest phase of my research, I met and interviewed sixsecond generation adults. Three of these participants were very open and revealed much about their childhoods and the impact these continue to have on their senses of self and belonging. Each was raised for a period outside their parental home. At the time, I noted this co-incidence though I had not sought it. In the early period, I met with one person four times, another twice and the last, once, all face-to-face, in their homes. These early interviews were structured around personal experiences of upbringing, home life, family, heritage, identity, ethnicity, and nationality. When meeting again, two were face-to-face interviews, again in their homes, and 
one was by telephone, though we latterly met for coffee outside the context of formal research. The more recent interviews revisited the earlier topics and included questions addressing wider political perspectives, such as the Windrush scandal, Brexit, and the increasingly hostile environment growing in the sociopolitical realm. All interviews throughout the two research periods were conducted in English, audio recorded, and transcribed and coded by me.

Their accounts made me realize that their personal histories were neither isolated nor accidental. It is toward a more complex understanding of how these adults reconcile their multiple heritages as children of Empire, of being raised partly or wholly outside their natal homes, and of their unwitting immersion into an intolerant, racist, and hostile post-colonial environment while still realizing some sense of community and belonging, that this article proceeds.

\section{Rupture and Family Life}

The three participants are Toyin, Louis, and Remi (all names have been changed to preserve anonymity). Both Toyin and Louis were born in London in the late 1960s. Each was 39 when we first met in 2005 and 2006, and 52 at our most recent meetings in 2019. Remi was born in Kent. She was 52 when we first met in 2005, and 65 in 2019. In this section, I detail their earlier memories of childhood and the impact family rupture had on their senses of belonging.

Toyin is one of seven children and works in social care. The third born in her family, her parents came to the UK to gain skills for an envisaged return. They used foster care to support competing demands on their time and energy. Toyin's parents left their eldest child behind in Nigeria, and the first two born in the UK were fostered to a white English family in Kent. Toyin's mother could not manage to work to support her husband's study and look after two young children, with another soon on the way. Toyin was six weeks old when she went to live with her foster family and four years old when she returned. She shares how much she loved living in the countryside with 'an English woman and her family' (2006) whom she refers to as her nan. She enthused that she 'really loved it there because there was the sense of freedom, the countryside...and sitting on [her nan's] lap in front of a massive fire' (2006). She reveals that when she returned to her natal home, once her parents had bought a house, she found it:

Quite disturbing. 'Cause obviously moving from a settled environment and all that I knew to coming back and having to be part of a family again with other siblings and the discipline that was there and stuff like that, I really hated. [I felt like I was being] forced to eat food, being shouted at, and had to do things in a certain way because my dad was quite a strict guy. (2006)
Her parents followed the tradition of eating separately from the children. For Toyin, because she struggled with her father's disciplinary focus, this was a welcome respite from the demands of tradition, albeit one granted by attending to tradition. As she says: 'I don't really have a strong relationship with my father...so I was quite happy not to be in that space, because it would be more criticism basically' (2006). She recognizes now that times were hard for her parents and their need to seek support; she also recognizes that her father was trying to teach his children to think for themselves. Yet, she found the change from what she perceived as an idyllic life of freedom to a harsh life of tradition too much to broker:

Being born here and seeing how things were in England and then going home, I always used to feel like that when I was at school, I used to feel free, I was in England....It was kind of like, this thing called Mr. Ben....It's this children's [television] programme and every week he'd be in different costumes and he'd go through this door and he'd step into this different world. And it felt like basically that. You opened the door and it's like "Ok, I'm in Africa." (2006)

The challenges of migrating, working, studying, bearing and raising children not only took their toll on Toyin; these also impacted upon her parents. Her mother and father eventually separated, and while her father returned to Nigeria for a period of time, he has since remarried and now moves between the two countries. Her mother continues to live in the family home in London. Her own dreams to return and retire have been shattered, because, as Toyin comments, the country has changed so much, 'she doesn't feel like it's home anymore' (2006).

Louis is the eldest of three boys and works in the performing arts. Although childhood sweethearts, his parents came to Britain separately in the late 1950s, his mother to study nursing and his father to study accounting. They met again in London and married. Louis feels that his mother disappointed her family back home by marrying, as she was sent to England to better her circumstances and upon her return to Nigeria, her family's. Louis's early years were spent together with his family in a Yoruba household, but with practices he didn't quite understand, such as his father always eating first and alone. He also acknowledges that family life was difficult, with a 'quite violent minded, utterly controlling' (2019) father and a distant mother. When he was 11, the family underwent a three-way split. His mother and father separated, each returning individually to Nigeria, and he and his brothers were sent to English boarding schools. This became an identity crisis moment for him, as before he had used his Yoruba name, but in boarding school, he adopted an English one, to help him adjust. His father eventually returned to London with a Sierra Leonese woman, and the family reconstituted anew. He left boarding school and went to a local state school, which he found a more nourishing experience. 
His mother remained in Nigeria and continues to live there still.

As a young adult, Louis started running with the 'wrong crowd' and served time in prison, which he said was 'devastating' (2006). At 21 and at a turning point, he found a connection between himself and his Nigerian heritage, which he had struggled to understand when his father practiced elements of it:

That was one of the great epiphanies for me when I was 21, when I was in that trouble. "What am I doing, expressing myself in this way?" All those people who have come before me, given so much, what are you offering back? Is this what you'll go down as, one of the ancestors, "Oh yeah he got into a bit of trouble."...You know what I mean? (2006)

While not quite sure of his Nigerian culture, he was able to conceptually emplace himself within its lineage, which helped him to change his behavior and do things differently. He understood that his father, as head of the family, was aiming to connect with the ancestors and protect the family by eating first and by himself. Yet, Louis felt that his father had lost sight of why he was enacting this ritual and was just eating alone. Louis's ability both to see this rupture in his father and to see beyond this to the lineage of ancestors striving for positive change helped him to change his path and work toward leaving a positive legacy.

Remi was born to a Yoruba father, whom she has never met, and an English mother. Now retired, she worked in the third sector as a diversity and inclusion trainer, with personal interest in the creative industries. Not only was she born into a mixed relationship, her mother did not raise her. Remi was raised in the Barnado's system of institutionalized and foster care (Barnardo's is a British charity founded by Thomas John Barnardo in 1866 to support vulnerable children). She did not meet her mother until she was in her 30 s. Remi realizes that she has had a 'strange background' as she terms it, in that she was 'badly abused in my childhood...[living with all the] deprivations you could imagine as a child' (2005). She said this experience 'instilled in her a sense of not belonging anywhere on the planet and seeking that out' (2005). Remi's fostering experience, unlike Toyin's, was one of not belonging, where Remi recollects that she did not know who her parents were or have anyone around her who looked like her:

My life's work has been understanding myself as a human being. What it means to be a nigger?...The interesting thing is just how, in my explanations to [this question], cause me to understand what my heritage is and what my sense of belonging is and therefore who I am. (2005)

She comments that there wasn't anyone growing up in the '50s and ' 60 s who had a 'darker shade of pale as a complexion' that wasn't a victim of racism, and offered that you either addressed it and became a better person or you didn't and became a bitter one (2005). She did not know her natal family growing up and questioned her physical features in relation to those of her white foster family. Her sense of belonging to her mother's family did not come until she was in her 30s. Remi's mother had kept the birth of her mixed-race daughter concealed from her family, which the institutionalization to Barnado's facilitated. However, upon visiting her maternal grandmother, who was gravely ill, the grandmother recognized that she was her daughter's child and conveyed this to Remi, in gestures and unspoken language:

She pointed to the photograph on the cupboard and told me to bring the photograph. She didn't speak to me; it was all nonverbal communication. And so, I brought the photograph and I put it in front of her and she pointed to all the women. It was a photograph of a series of women, northern women, with their pinnies on and their arms folded.....And she pointed to them all and she pointed to me, and her, and to the picture. So, she made it very clear that I was part of her family. (2019)

Remi said that this was a 'life-changing' (2005) event, to have that sense of belonging, and a place in the family line. It helped her to make sense of herself and where she fitted within a biological family. While she has not been able to connect with members of her paternal family, Remi's experiences of being othered from Englishness prompted her to seek her Nigerian ancestral belongings outside the UK, travelling to West Africa and being given a Yoruba name by a priest, which she uses as her given name.

The end of Empire has visited upon each of these children extremely harsh circumstances. For Toyin, her early years in foster care remained a comparison her family home could never live up to with a disciplinary structure that left her feeling trapped in an alternative reality. Louis's family migration and subsequent three-way rupture created alienation among each of his parents and himself, where a tumultuous childhood led to personal crisis. This he resolved through a purposeful connection to his ancestors as an imagined heritage holding him to account. In a similar vein, Remi also has striven to transcend some of her childhood traumas and her lack of belonging anywhere, by seeking out and finding connections beyond her immediate kin, and more generally among the wider Nigerian and African diaspora.

\section{Exclusion in Micro and Macro Spheres}

In addition to having to adjust to living in between different conceptual worlds, of being born in Britain, of having a family heritage from elsewhere, of living away from natal family and undergoing different levels of trauma re- 
lated to childhood experiences, these three members of the second generation also had to contend with racism and the general hostility that attended the decolonial era and after. Intolerance and outright abuse are not new, as Balibar (as cited in Modood, 1997) contends, but is something that has been consistently present, though variable in its vocality. Toyin affirms this by stating that:

Even though we live in a multicultural society, there has always been this underlying [sense of unwelcome].... Obviously with Brexit and the focus on trying to control immigration and stuff like that, this has given rise to people who have always been silent to find a platform to air their concerns or views about having immigrants in their country. (2019)

She shares her incredulity about this belief, stating that whatever made anyone think that people of color were lesser, they should have outgrown that by now, 'because you have seen us, you [have] lived with us, you know what we are about' (2019). In reflecting on the past 20 years in the UK, Remi offers personal experiences that countervail Toyin's expectation of advancement in thinking. Due to lack of affordability of housing in more cosmopolitan areas, Remi bought a house in a part of London that was white working class and right wing. Her reception was far from pleasant:

When I first moved [here] in 2000, I was called "WOG," "nigger," all of those things, which I had not heard for many years.... On a bus [I was] told, "Don't sit there, nigger, next to my child, move".... had shit thrown on my windows. I came home to find dog shit all over my door and my windows. (2019)

She continues by saying that in the intervening period, when more people from Africa and Brazil moved in, the abuse died down. However, with the election of Trump and the Brexit vote, she noted that these defamations began anew. 'Suddenly you heard these words again. "Oh, we've got so many niggers in this neighborhood." I heard that on the street, I was really shocked' (2019). The relative quiet was not necessarily to do with acceptance of multiculturalism after the dawn of the 21st century but reflected a period of dormancy until reinvigoration in the return of a polarized macro-political climate.

Louis has had similar experiences throughout his life, with what he terms 'tragic,' 'relaxed' racism on the one hand and a sense of toleration, that people were not being truly honest about how they felt, on the other (2019). He recounted examples of being feared as a 'sixfoot black guy' (2019) with people clutching their bags as he walked past; even now as one who walks with a crutch due to a semi paralyzing illness he is recovering from. As he says, 'I have this distinct feeling that sometimes they think I am just pulling one off. I am just going to drop [the crutch and] grab something' (2019). Yet he acknowledges that intolerance and fear are complicated.
In speaking about Brexit and the challenges presented about Ireland, he says:

If you are looking at Ireland...people who have the same pigmentation....Seeing this kind of way the Irish have been treated....They have had massive issues, historically...of being treated by the upper classes and the higher classes like shit. And in a sense, I conclude, how are we going to deal with racism when you don't even like your own kind? (2019)

Louis complicates the notion of not belonging as being beyond color and beyond heritage, by bringing in class and the differentials in power enacted at different scales. Remi raised power in our first meetings, stating that in matters of racism or other structural inequalities 'it's always a matter of power....Who has the power?' (2005). The narratives and experiences above raise core issues about the complexities surrounding not belonging. Notbelonging is shaped by several factors and include, but is not limited to, intersections of class, gender, and race, as well as relative power within existing structures and identity politics. These factors are subject to permutation and change, depending on differentials being played out at any given time in micro and macro spheres.

\section{Recognition and Belonging}

Given that not-belonging is a fragmented and constructed process, so too is belonging. When thinking about this topic, of where each belongs and feels safe, Louis, Toyin, and Remi each share their thoughts on its complexity, as not being based only on biological or cultural inheritances, but also on connections in which their experiences or imaginings are aligned with others.

Family remains a point of comparison and contention when thinking about belonging. Louis draws a parallel between the divisions within his family to that of the nation, underlining how senses of belonging may be made tenuously, that is, with limited opportunity to assess alternatives:

Ask people a simple question, yes or no. It is quite a simple question. Like my dad said, "Do you want to stay here with me, or do you want to go with your mum?" Even at 11, I said, "Well, I want to stay here." I didn't know anything about Nigeria. I had some notion of it. If you ask a simple question, you can answer it simply, but surely the aftermath, you have to realize, is extremely complex. And this is what's happened with Brexit. It is a very complex answer to give! You want to break a whole family up? "I'm leaving" or "I'm staying." "Let's split the family up!" How is that all going to affect people? (2019)

Louis's family situation, of a three-way split, has given him a deep understanding about declarations of belonging made with limited opportunity to understand their 
consequences. Even though he acknowledged earlier that his father was 'not an easy man' (2019), he made the choice to remain with him, when offered the alternative of a relative unknown. When speaking of a visit he made to Nigeria as a young boy, he noted that:

You realize when you go back to [what] home was for your parents, you realize who you are, because they tell you who you are. They go, "Hey English boy, English, you think you're Yoruba?" ...They can tell, from the way you walk. So, culturally, I'm English. Genetically, I'm not. What is English, genetically? (2005)

Louis adds that it can feel uncomfortable to state that one is English. In our most recent meeting, he revised his identification to be 'more British than English' (2019). Both markers have negative associations, given England's and Britain's historical mistreatment toward those of his ancestry. Nevertheless, he argues that one must resolve such identity crises and find composure: 'My journey has been one of discovery, and I know people in Scotland, Ireland, and Wales, people that I have visited. And that is a really healthy thing to do' (2019). He further offers that resilience, forged by surviving difficult situations, is another way. He reflects on the trouble he got into as a young man, and although he regrets the negative impact it continues to bear on his life, in having a criminal record, the resilience it has helped him develop enables him to be content with himself amid life's difficulties. Drawing on his actor training, Louis says it is important to 'never be desperate' but to come back to one's own 'grounding' (2019). For Louis, grounding affirms a neutral space to begin again.

Toyin suggests that being able to 'feel like yourself, really comfortable, loved, secure, with people around you that you can trust' (2006) is not a condition of biological families, but can be found outside that. She sees herself as 'British by birth, but ethnically Nigerian' (2019), a by-product of her experiential duality. While her father insisted she have a Nigerian passport in addition to her birth passport from the UK, Toyin's sense of belonging is not limited to these alternatives. Complicating that notion, Toyin noted that as a child she had felt belittled by her Caribbean peers, who had made fun of her Yoruba name and the elaborate hairstyles her mother constructed (2006). Yet, Toyin equally acknowledged that many Caribbean children shared 'a lot of what happened to me as a child' (2006) around harsh discipline and having to eat foods they did not like at home. While she did visit Nigeria and picked up some Yoruba language, she feels deprived for not being able to participate more fully in this aspect. She derives recognition from her name, a point of contention in the past, but a point of pride in who she is now. Whereas Toyin did not change her name, she uses a shortened version of the original, Oluwatoyin. Even abbreviated, she is very sensitive to its mispronunciation, which feels like her identity is 'being stripped away'
(2006). She notes how a Nigerian man she worked with made her 'shake' when he said her name, hitting her core with its force in being said correctly.

She feels now that communities of practice, 'with people who share the same interests as me' (2019), enable her to belong and be herself. When asked, she offers a life philosophy that transcends differences:

You would have thought by now we would have grown out of trying to define people by different things: your race, gender, religious beliefs, sexual preference. At the end of the day, we are human beings. We...want the same things in life. (2019)

Although still struggling to find herself, Toyin acknowledges that simplistic identity markers are insufficient for her or others to find community.

Remi has developed strengths amid persecution and has turned exclusions to her advantage. Remi sees herself as part of a diaspora who has been 'displaced from a point of historical upheaval' (2005). She identifies with the African diaspora as a heritage that moves toward a collective of belonging, transcending national boundaries and temporal constraints. At the same time, she also acknowledges that belonging comes through personal choices, stating that people tend to create who they are. For her, this is through 'who we've had in our family history, in our family tree, in our communities, in our countries where we grow, who we identify with' (2005). Even though her various families have not treated her well, Remi nevertheless refers to connectivity and belonging through the idiom of family. This was not just the recognition she received from her grandmother which placed Remi in her line of descent, but also the recognition Remi had, for herself, as part of that line. When speaking of the photograph her grandmother pointed to, she says, she could see 'myself and my daughters in those women' (2005). Remi extends these recognitions of belonging beyond biological inheritances to others she incorporates as new families:

One of the things [my partner] always says about me is that I have created many families. And I think that is possibly because of not having one, per se. My communities are communities that I feel some kind of bond with, in some way. (2019)

Remi's sense of connection is multiple. Despite a fragmented and abused early life and having suffered further abuse as racially other in the society where she was born and of which, biologically, she is a part, Remi creatively engages with imagined and experienced pasts toward making families anew in the present.

While each has had to navigate biological, cultural, and political inheritances and exclusions, each has come to find that while these circumstances have set a frame around their lives, these do not fully determine where and how they belong. 


\section{Discussion}

Children who were born in the UK to emigrating Nigerians at the dawn of independence have had to struggle with multiple exclusions from home culture and host society. Complex upbringings, arising in part from the difficult circumstances their parents faced upon arrival in the UK, have profoundly impinged on their children's senses of identification and belonging when young. The implications of these circumstances have continued to reverberate throughout their lives into middle age. As a result of individual family difficulties - whether around management of productive and reproductive resources, marital breakdown, or concealed inter-racial pregnancy-from early ages, these children have had to navigate the difficulties of difference, discord and disconnect, amid variable constructions of home and family. Further, the impact of racism and non-acceptance of those born in the UK from the former colonies have compounded senses of alienation and not-belonging. For those children who suffered family breakdown and ended up in some form of institutionalized care, the alienation and searching has taken them an additional step further into confusion and disorientation. As Wells (2017, p. 230) states, no matter how old they are, a child is a 'living person with a complex subjectivity' and family crises leading to separation have significant impacts on how they understand themselves.

The now adult children in this study have explored their subjectivities in detail and have made understanding themselves and their circumstances of youth a lifelong process. Although far from a representative sample, and with each seemingly having had exceptional circumstances in their families, with Louis' family experiencing a three-way split, Toyin's using the fostering route to facilitate family settlement in the UK, and Remi's family being a mix of multiple estrangements and fostering, their stories coalesce around the difficulties of being accepted and achieving recognition, in their ancestral cultures and in British society. As a point of departure, Ahmed (2017, p. 133) contends that 'so much political work begins with moments of disorientation'; where lack of fit can give rise to reflection on the politics of belonging, for oneself and in relation to wider society. Collectively, these adults have suffered much, in confusion, disorientation, trauma, rupture, imprisonment, overt racism, violence, isolation, and alienation.

While recent events have brought to public attention the mistreatment of the Windrush generations and other immigrants, with focus on a government imposed 'hostile environment,' not being welcome in Britain has a much longer trajectory. The myths of belonging in Britain, being based on an unchanging homogeneity (Yuval-Davis, 2004, p. 220) persist, and in the case of these three, particularly reflect the inability to include 'extra-European/non-white' (Modood, 2007) ethnicities, even when born in the UK. This calls into question the resistance to multiculturalism in British society and the long-standing intolerance and outright antagonism to- ward those not phenotypically or culturally 'British.' In defining multiculturalism, Modood (2010, p. 124) offers that what is needed is:

A vision of citizenship that is not confined to the state, but dispersed across the society, compatible with the multiple forms of contemporary groupness, and sustained through dialogue; plural forms of representation that do not take one group as the model to which all others have to conform; and new, reformed national identities.

I would argue that amid the struggles endured by this small representation of the 'consequences of Empire' (Gilroy, 2004), these adults have embraced and embody multiculturalism in its plurality as a life project. While Imoagene (2012, p. 2171) argues that Britain needs to adopt 'national myths that are powerful enough to unite and inspire an increasingly diverse population,' the cases presented here suggest that it is not the 'diverse population' that remains uninspired to be part of Britain, but it is the reluctance of Britain to include them in its national myths. Louis embraces his Englishness, while Remi opts for a more transnational identification, and Toyin maintains nostalgia for her English childhood, erstwhile accepting and embracing being a British Nigerian. To this end, each has sought, or created, communities of belonging that are outside singular identity markers, whether this be related to race, place, nation, family, or heritage. As May, Modood, and Squires (2004, p. 9) note, the 'origin, content and form of ethnicity are all open to negotiation, reflecting the creative choices of individuals and groups as they define themselves and others.' As seen here, these children of Nigerian émigrés have been forced to confront and refute immutable markers, and by making sense of their upbringings and subsequent experiences, of inclusion and exclusion, have demanded that they move into plural realms and more complex understandings of their identities and that of others.

While not claiming representation of all second generation Nigerians in the UK, nor also of those who underwent periods of time being raised outside of their natal homes, this article suggests that attention to the 'intersecting histories of family and decolonization' (Bailkin, 2009 , p. 121), of discord in the former and hostility in the latter, offers insight into how situations faced in early years continue to impact across the life course. It also suggests that a longitudinal perspective, combined with micro and macro contexts, opens the space for revealing how people continue to come to terms with complex situations, and from within these, also draw on resilience forged in the process to transform these intricacies into a richer, plural sense of identity and belonging.

\section{Conclusion}

This research found that children of post-colonial migrants from Nigeria endured much suffering as a conse- 
quence of family breakdown and hostile environments attending the end of Empire. The difficulties for parents in fulfilling their aspirations had long term devastating impacts on themselves and their children, which continue to reverberate decades after into adulthood. Indifferent and shortsighted post-colonial policy did not adequately facilitate or embrace those who moved from former colonies into the center of Empire. Initial welcomes quickly transformed into indifference and hostility once in England. Nor did exclusive national myths on who can be or become British make space to include a multiplicity of identity and belonging. Rather, reductive exclusions left vulnerable young people to find their own solutions. A small sample of second-generation Nigerians have found that embracing multiplicity, both in spite of and in response to these challenges, has helped them to arrive at multiple identifications and within various communities of belonging. Their disorientations have enabled them to reflect on their specific lives and situate these within wider macro-political contexts, as part of the larger issue attending the ongoing period of post-colonialism.

\section{Acknowledgments}

I wish to thank the Arts and Humanities Research Council (AHRC) for funding my doctoral studies. I also wish to thank my research participants for their time and openness in sharing reflections on their lives with me.

\section{Conflict of Interests}

The author declares no conflict of interests.

\section{References}

Ahmed, S. (2017). Living a feminist life. London and Durham, NC: Duke University Press.

Bailkin, J. (2009). The postcolonial family? West African children, private fostering, and the British state. The Journal of Modern History, 81(1), 87-121.

Bell, D. (2018). The indifferent. Qualitative Research in Psychology, 15(2/3), 140-155.

Botticello, J. (2009). Fashioning individuality and social connectivity among Yoruba women in London. In D. Miller (Ed.), Anthropology and the individual (pp. 131-144). Oxford: Berg.

Botticello, J. (2012). Yoruba-Nigerians, cosmopolitan food cultures and identity practices on a London Market. In P. Williams-Forson \& C. Counihan (Eds.), Taking food public (pp. 425-437). London and New York, NY: Routledge.

Ellis, D. (2001). The produce of more than one country: Race, identity, and discourse in post-Windrush Britain. Journal of Narrative Theory, 31(2), 214-232. Gilroy, P. (2004). After empire: Melancholia or convivial culture? Abingdon: Routledge.

Hallgren, R. (1991). The good things in life: A study of the traditional religious culture of the Yoruba people. Lund: Plus Ultra.

Harris, H. (2006). Yoruba in diaspora: An African church in London. New York, NY: Palgrave Macmillan.

Imoagene, O. (2012). Being British vs. being American: Identification among second-generation adults of Nigerian descent in the US and the UK. Ethnic and Racial Studies, 35(12), 2153-2173.

Kopytoff, I. (1986). The African frontier, the reproduction of traditional African societies. Bloomington, IN: Indiana University Press.

May, S., Modood, T., \& Squires, J. (2004). Ethnicity, nationalism, and minority rights: Charting the disciplinary debates. In S. May, T. Modood, \& J. Squires (Eds.), Ethnicity, nationalism and minority rights (pp. 1-23). Cambridge: Cambridge University Press.

Modood, T. (1997). 'Difference,' cultural racism and antiracism. In P. Werbner \& T. Modood (Eds.), Debating cultural hybridity: Multi-cultural identities and the politics of anti-racism (pp. 154-172). London: Zed Books.

Modood, T. (2007). Multiculturalism. Cambridge: Polity Press.

Modood, T. (2010). Still not easy being British: Struggle for multi-cultural citizenship. Stoke-on-Trent: Trentham Books.

Oyetade, A. (1993). The Yoruba community in London. Journal of African Languages and Cultures, 6(1), 69-92.

Powell, E. (1991). Reflections of a statesman: The writings and speeches of Enoch Powell. London: Bellew.

Wells, K. (2017). Globalizing child circulation: The care of children who are privately fostered across international borders. In J. Horton \& M. Pyer (Eds.), Children, young people and care (pp. 218-233). London: Routledge.

Wells, K. (2019). 'I'm here as a social worker': A qualitative study of immigration issues and safeguarding children in private fostering arrangements in the UK. Child Abuse Review, 28(4), 273-286.

Yuval-Davis, N. (1997). Ethnicity, gender relations and multiculturalism. In P. Werbner \& T. Modood (Eds.), Debating cultural hybridity: Multi-cultural identities and the politics of anti-racism (pp. 193-208). London: Zed Books.

Yuval-Davis, N. (2004). Borders, boundaries and the politics of belonging. In S. May, T. Modood, \& J. Squires (Eds.), Ethnicity, nationalism and minority rights (pp. 214-230). Cambridge: Cambridge University Press.

Yuval-Davis, N., Wemys, G., \& Cassidy, K. (2018). Everyday bordering, belonging and the reorientation of British immigration legislation. Sociology, 52(2), 228-244. 


\section{About the Author}

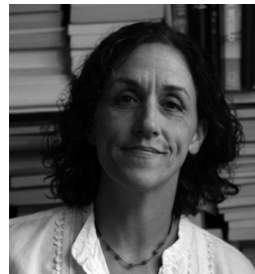

Julie Botticello holds a PhD in Anthropology and has worked in UK higher education since 2008. Her research centers on people, knowledge, and equity. She works with marginal populations, maintaining an interest in post-colonial populations, migrants to the UK, and the British working classes. Her research interests concern alternative epistemologies, including embodied knowledge, social justice, and their relationships in local and global contexts. 